\title{
A note on the distribution of insulin receptor mRNA in tissues of neonatal Holstein calves ${ }^{*}$
}

\author{
G.W. Liu', Z.G. Zhang ${ }^{1,2}$, X.L. Zhu' ${ }^{1}$, Z. Wang ${ }^{1,4}$, C. Xia ${ }^{3}$ and C. Xu ${ }^{3}$ \\ ${ }^{1}$ Laboratory of Animal Nutritional and Metabolic Diseases and Toxicopathy, \\ College of Animal Science and Veterinary Medicine, Jilin University \\ Changchun, Jilin, 130062, P.R. China \\ ${ }^{2}$ College of Veterinary Medicine, Northeast Agriculture University \\ Harbin, Heilongjiang, 150030, P.R. China \\ ${ }^{3}$ College of Animal Science and Technology, \\ Heilongjiang August First Land Reclamation University \\ Daqing, Heilongjiang, 163319, P.R. China
}

(Received 6 March 2009; revised version 14 July 2009; accepted 6 November 2009)

\begin{abstract}
Characterization of the distribution of insulin receptor (InsR) mRNA in tissues is crucial to understand insulin physiology in dairy cattle. The expression of the InsR gene in various tissues of three male neonatal Holstein calves was analysed using reverse transcription polymerase chain reaction. The results showed that the InsR mRNA was detectable in the liver, subcutaneous adipose, Semitendinosus muscle, pancreas, kidney cortex, spleen, heart, lung, mesenteric lymph node, aorta, duodenum, colon, hypothalamus, pituitary, cerebral cortex and cerebellar cortex. Expression of InsR mRNA was particularly higher $(\mathrm{P}<0.05)$ in the liver, Semitendinosus muscle, pancreas, aorta, hypothalamus and pituitary tissue than other tissues detected. The broad tissue expression of the InsR gene indicates that the InsR has important physiological functions in multiple tissues in neonatal Holstein calves.
\end{abstract}

KEY WORDS: insulin receptor, RT-PCR, calf

\section{INTRODUCTION}

Insulin and IGF-2 play important roles in animal organism. Insulin takes part in promoting cell proliferation, differentiation, as well as protein, fat, glycogen

\footnotetext{
${ }^{*}$ Supported by the National Natural Science Foundation of China (30230260, 30600441)

${ }^{4}$ Corresponding author: e-mail: wangzhe500518@sohu.com
} 
synthesis. Main effect of IGF-2 are promoting the growth and the role of insulinlike. The insulin receptor (InsR), like other protein hormone receptors, is localized to the plasma membrane. InsR is a tyrosine kinase that is composed of two $\alpha$ subunits and two $\beta$ subunits linked by disulphide bonds. It acts as an enzyme that transfers phosphate groups from ATP to tyrosine residues on intracellular target proteins.

Binding of insulin to the $\alpha$ subunits causes $\beta$ subunits to autophosphorylate, and thus activate the catalytic activity of the receptor. The activated receptor then phosphorylates a number of intracellular proteins, to alter their activities, thereby generating a biological response. InsR has been reported to play a role in various physiological functions such as mediating IGF-2 and insulin action to further mediate metabolic responses (Rother et al., 2000). As the first step towards understanding the effects of the InsR in various tissues of the calf, it is necessary to characterize the gene expression of InsR in various tissues. InsR mRNA has been detected in the liver, duodenum, colon, jejunum (Hammon et al., 2002; Pfaffl et al., 2002; Georgiev et al., 2003; Georgieva et al., 2003; Ontsouka et al., 2004), and in the luteum, leukocytes, retina (Gosbell et al., 2002; Neuvians et al., 2003; Nielsen et al., 2003), but the other tissues of neonatal calf have not been examined. The key objective of this study was to determine the mRNA expression of InsR in various tissues of male, neonatal Holstein calves. We used RT-PCR to examine the relative expression of the InsR gene.

\section{MATERIAL AND METHODS}

The experiment was conducted at the Laboratory of Animal Nutritional and Metabolic Diseases and Toxicopathy, the College of Animal Science and Veterinary Medicine, University of Jilin. Three male neonatal Holstein calves (body weight: $40.5 \pm 5.28 \mathrm{~kg}$ ) were used in this study according to procedure approved by the Faculty Academic Committee. Within $30 \mathrm{~min}$ of slaughter, 16 tissue types were collected from each calf: liver, subcutaneous adipose depots, Semitendinosus muscle, pancreas, kidney cortex, spleen, heart, lung, hypothalamus, mesenteric lymph node, aorta, duodenum, colon, pituitary, cerebral cortex and cerebellar cortex. Samples were snap-frozen in liquid nitrogen and stored at $-80^{\circ} \mathrm{C}$.

Total RNA was isolated in accordance with the manufacturer's (Invitrogen, USA) instructions. Total RNA was quantified by absorbance at $260 \mathrm{~nm}$ in a spectrophotometer; only samples with a 260:280 nm ratio $>1.9$ were used for further analysis. To verify integrity, total RNA $(10 \mu \mathrm{g})$ was electrophoresed on a $2 \%$ agarose gel in Tris-borate EDTA buffer and stained with ethidium bromide. Cellular RNA with intact 28S and 18S ribosomal bands were used in subsequent 
analyses. Isolated RNA was stored at $-80^{\circ} \mathrm{C}$ until the RT-PCR assay.

All of the other reagents used were from TaKaRa Biotechnology Co. Ltd. (Dalian, China). First-strand complementary DNA (cDNA) was synthesized from $2 \mu \mathrm{g}$ of total RNA in a $20 \mu 1$ reaction volume with a final concentration of 50 pmol of Oligo (dT)18 primers, $2.0 \mu \mathrm{l}$ of dNTP Mixture (10 mmol/l each), $4 \mu 1$ of $5 \times$ Reverse Transcriptase buffer, $10 \mathrm{U}$ of AMV Reverse Transcriptase, $20 \mathrm{U}$ of RNase Inhibitor, and $1.5 \mu 1$ of RNase-free distilled water. After mixing, the mixture was incubated at room temperature for $10 \mathrm{~min}, 42^{\circ} \mathrm{C}$ for $1 \mathrm{~h}$, and finally $0^{\circ} \mathrm{C}$ for $2 \mathrm{~min}$. Two microlitres of the first-strand cDNA reaction were amplified in a 50 $\mu 1$ reaction volume containing a final concentration of $5 \mu 1$ of $10 \times$ Ex Taq buffer, $4 \mu 1$ of dNTP Mixture $2.5 \mathrm{mmol} / 1 \mathrm{each}), 0.25 \mu \mathrm{l}$ of Ex Taq $(5 \mathrm{U} / \mu \mathrm{l}), 2 \mu 1$ of each primer $(10 \mathrm{pmol} / \mu \mathrm{l})$, and $34.75 \mu \mathrm{l}$ of RNase-free distilled water. Following an initial denaturation at $94^{\circ} \mathrm{C}$ for $3 \mathrm{~min}, \mathrm{PCR}$ was performed for a variable number of cycles of denaturation at $94^{\circ} \mathrm{C}$ for $45 \mathrm{~s}$, the specific annealing temperature for $50 \mathrm{~s}$, extension at $72^{\circ} \mathrm{C}$ for $1 \mathrm{~min}$, and a final extension at $72^{\circ} \mathrm{C}$ for $10 \mathrm{~min}$ in the last cycle. The PCR products were electrophoresed on a $2 \%$ agarose gel in Trisborate EDTA buffer and stained with ethidium bromide. Images were captured and the PCR product densities were analysed with SPSS10.0.

The primers of InsR and $\beta$-actin were designed based on the publicated sequence of GenBank, the annealing temperature, length, Pubmed access number of the primes and PCR cycles as Table 1.

Table 1. Primer pairs for RT-PCR amplification of the InsR and $\beta$-actin genes, annealing temperature (AT), number of amplification cycles, and length (base pairs, bp) of PCR products

\begin{tabular}{|c|c|c|c|c|c|}
\hline Target & Primers & AT & Cycles & $\begin{array}{l}\text { Length } \\
\text { bp }\end{array}$ & $\begin{array}{c}\text { Pubmed access } \\
\text { number }\end{array}$ \\
\hline InsR & $\begin{array}{l}\text { F: 5'-AGGAGCTGGAGGAGTCCTCGTTCA-3' } \\
\text { R: 5'-CATTCCCCACGTCACCAAGGGCTC-3' }\end{array}$ & $59^{\circ} \mathrm{C}$ & 30 & 147 & XM_590552 \\
\hline$\beta$-actin & $\begin{array}{l}\text { F: 5'-TCATCACCATCGGCAATGAG-3', } \\
\text { R: 5'-CATCGTACTCCTGCTTGCTGA-3' }\end{array}$ & $57^{\circ} \mathrm{C}$ & 26 & 351 & BC142413 \\
\hline
\end{tabular}

For each tissue and target gene, negative controls without reverse transcriptase yielded no amplification, confirming that genomic DNA was not amplified. The B-actin gene was used as an internal control.

In a preliminary study, cDNA samples in duplicate, were amplified from 18 to 34 cycles for $\beta$-actin, and from 22 to 36 cycles for InsR. The average of three ratios of InsR to $\beta$-actin were used to model the abundance of InsR and $\beta$-actin PCR products as a function of the number of amplification cycles. To ensure that the PCR was conducted in the linear range of amplification, cDNA samples were amplified for 30 cycles for InsR and 26 cycles for $\beta$-actin (Table 1). The PCR products were quantified as described above, and the ratio of InsR to $\beta$-actin in 
duplicate RNA samples was analysed by ONE-WAY ANOVA using SPSS 10.0, Duncan's LSD test.

\section{RESULTS}

The amplification plots were shown in Figure 1. The distribution of InsR mRNA in various tissues were shown in Figures 2 and 3. The results showed that the InsR mRNA was detectable in the liver, subcutaneous adipose, Semitendinosus

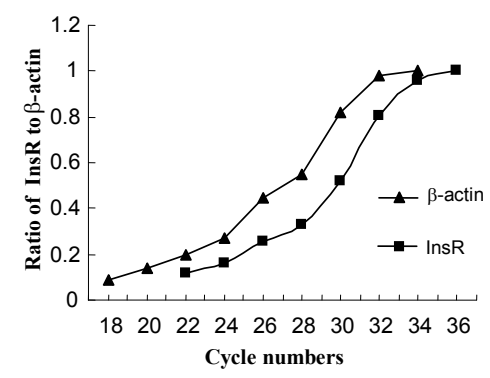

Figure 1. Semiquantitative RT-PCR to determine the relative abundance of InsR mRNA in the liver of neonatal Holstein calves. The average of three ratios of InsR to $\beta$-actin was used to model the abundance of InsR and $\beta$-actin PCR products as a function of the number of amplification cycles

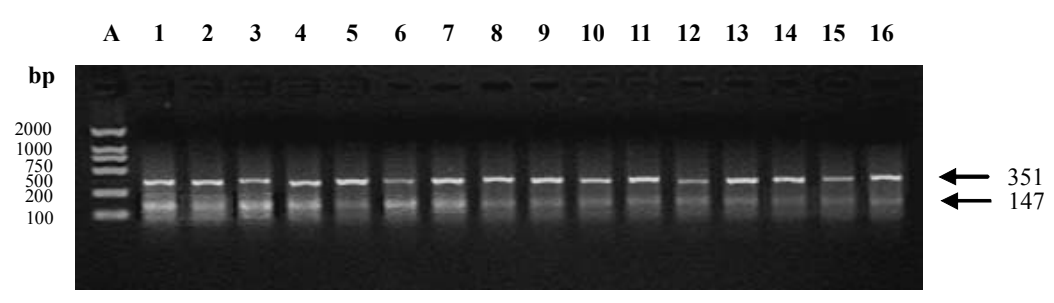

Figure 2. Detection of mRNA corresponding to InsR, and $\beta$-actin in various tissues of of InsR to $\beta$-actin a typical neonatal Holstein calf by reverse transcription polymerase chain reaction. Lanes (Ln) A, DL 2000 DNA Marker; Ln 1, liver; Ln 2, Semitendinosus muscle; Ln 3, hypothalamus; Ln 4, aorta; Ln 5, Subcutaneous adipose depots; Ln 6, pancreas; Ln 7, pituitary; Ln 8, cerebellar cortex; Ln 9, lung; Ln 10, cerebral cortex; Ln 11, kidney cortex; Ln 12, heart; Ln 13, spleen; Ln 14, colon; Ln 15, duodenum; Ln 16, mesenteric lymph node 


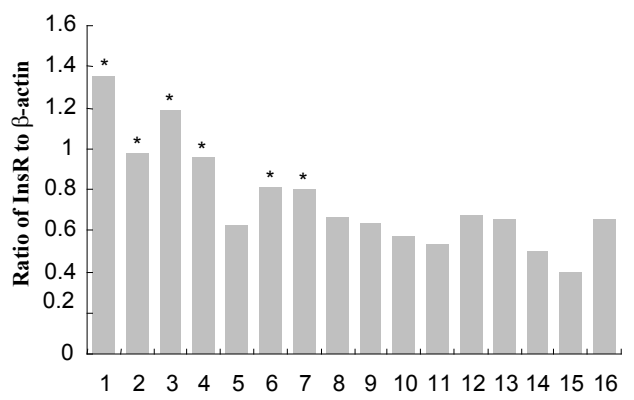

Figure 3. The ratio of mRNA abundance of InsR to $\beta$-actin in 16 tissues types from neonatal calves. Numbers 1-16 represent the lanes described in the legend for Figure 2

muscle, pancreas, kidney cortex, spleen, heart, lung, mesenteric lymph node, aorta, duodenum, colon, hypothalamus, pituitary, cerebral cortex and cerebellar cortex. Expression of InsR mRNA were particularly higher $(\mathrm{P}<0.05)$ in the liver, Semitendinosus muscle, pancreas, aorta, hypothalamus and pituitary tissue than other tissues detected.

\section{DISCUSSION}

Recent molecular biology studies have revealed the presence of InsR transcripts in the gastrointestinal tract of neonatal calf. This shows that the InsR is necessary for optimal pre- and postnatal growth and development (Hammon et al., 2002; Pfaffl et al., 2002; Georgieva et al., 2003; Ontsouka et al., 2004). The mRNA expression of InsR in the bovine corpus luteum suggests that InsR plays a major role in luteal development and function in bovine species (Georgiev et al., 2003). The role of InsR in glycometabolism and lipid metabolism is demonstrated by the presence of InsR transcripts in adipose tissue, Semitendinosus muscle, and the liver. The detection of InsR mRNA in the spleen and mesenteric lymph node suggests that the InsR is involved in immune function, which is confirmed by the identification of InsR in heifer leukocytes (Nielsen et al., 2003). InsR may also be involved in digestive, respiratory, renal, cardiovascular and endocrine functions as shown by the presence of InsR mRNA in various regions of the gastrointestinal tract, lung, kidney, aorta, hypothalamus and pituitary, respectively. The blood vessel wall also appears to be a target for insulin, as proposed by Vinters et al. (1987) and Chelikani et al. (2003). Because the InsR transcript was found in the hypothalamus, pituitary, cerebellar cortex and cerebral cortex, the InsR may be involved in the control of feeding, and mediating movement, senses and memory (Gao, 2003). 
The abundance of InsR mRNA was much higher $(\mathrm{P}<0.05)$ in the hypothalamus and pituitary compared with other tissues, which indicates that these tissues may play an important role in mediating IGF-2 and insulin activities.

\section{CONCLUSIONS}

In conclusion, our data on differential tissue expression of the InsR gene provide evidence for the potential involvement of the InsR in various physiological functions in multiple tissues of neonatal calves. The function of InsR in different tissues will be characterized in further studies.

\section{REFERENCES}

Chelikani P.K., Glimm D.R., Kennelly J.J., 2003. Short communication: Tissue distribution of leptin and leptin receptor mRNA in the bovine. J. Dairy Sci. 86, 2369-2372

Gao X., 2003. The effect of insulin on intake and body weight controlled by central nerve. Acad. J. Second Military Med. Univ. CPLA. 24, 529-531

Georgiev I.P., Georgieva T.M., Pfaffl M., 2003. Insulin-like growth factor and insulin receptors in intestinal mucosa of neonatal calves. J. Endocrinol. 176, 121-132

Georgieva T.M., Georgiev I.P., Ontsouka E., et al., 2003. Abundance of message for insulin-like growth factors-I and -II and for receptors for growth hormone, insulin-like growth factors-I and -II, and insulin in the intestine and liver of pre- and full-term calves. J. Anim. Sci. 81, 22942300

Gosbell A.D., Favilla I., Jablonski P., 2002. The location of insulin receptors in bovine retina and isolated retinal cells. Clin. Exp. Ophthalmol. 30, 124-130

Hammon H.M., Blum J.W., 2002. Feeding different amounts of colostrum or only milk replacer modify receptors of intestinal insulin-like growth factors and insulin in neonatal calves. Domest. Anim. Endocrinol. 22, 155-168

Neuvians T.P., Pfaffl M.W., Berisha B., Schams D., 2003. The mRNA expression of insulin receptor isoforms (IR-A and IR-B) and IGFR-2 in the bovine corpus luteum during the estrous cycle, pregnancy, and induced luteolysis. Endocrine 22, 93-99

Nielsen L., Rontved C.M., Nielsen M.O., et al., 2003. Leukocytes from heifers at different ages express insulin and insulin-like growth factor-1 (IGF-1) receptors. Domest. Anim. Endocrinol. $25,231-238$

Ontsouka C.E., Sauter S.N., Blum J.W., Hammon H.M., 2004. Effects of colostrum feeding and dexamethasone treatment on mRNA levels of insulin-like growth factors (IGF)-I and -II, IGF binding proteins- 2 and -3 , and on receptors for growth hormone, IGF-I, IGF-II, and insulin in the gastrointestinal tract of neonatal calves. Domest. Anim. Endocrinol. 26, 155-175

Pfaffl M.W., Georgieva T.M., Georgiev I.P., et al., 2002. Real-time RT-PCR quantification of insulin-like growth factor (IGF)-1, IGF-1 receptor, IGF-2, IGF-2 receptor, insulin receptor, growth hormone receptor, IGF-binding proteins 1, 2 and 3 in the bovine species. Domest. Anim. Endocrinol. 22, 91-102 
Rother K.I., Accili D., 2000. Role of insulin receptors and IGF receptors in growth and development. Pediat. Nephrol. 14, 558-561

Vinters H.V., Berliner J.A., 1987. The blood vessel wall as an insulin target tissue. Diabetes Metab. 13, 294-300 